\title{
The confluence area of Rhine, Meuse, and Belgian rivers: Late Pliocene and Early Pleistocene fluvial history of the northern Lower Rhine Embayment \\ history of the northern Lower Rhine Embayment
}

\section{W.E. Westerhoff ${ }^{1,}{ }^{*}$, H.A. Kemna ${ }^{2}$ \& W. Boenigk ${ }^{2}$}

1 TNO Geological Survey of the Netherlands, PO Box 80015, 3508 TA Utrecht, the Netherlands.

2 Geologisches Institut, Universität zu Köln, Zülpicherstrasse 49a, Germany.

* Corresponding author. Email: wim.westerhoff@tno.nl

Manuscript received: January 2008 accepted: February 2008

\section{Abstract}

The fluvial history of the northern Lower Rhine Embayment shows interplay of three main river systems: Rhine, Meuse and smaller rivers draining the central and northern part of Belgium.

The Pliocene and Early Pleistocene (pre-)Rhine and Meuse river systems had their conjunction in the southern part of the Roer Valley Graben between Aachen and Jülich. Despite slight differences in the heavy-mineral assemblages the lithological composition of the Pliocene deposits of the three river systems shows close resemblance and therefore they cannot be mapped separately. However, due to a marked change of the petrographical composition the Upper Pliocene and Lower Pleistocene deposits of the Rhine are easily recognised and as a result Rhine and Meuse deposits can be mapped separately upstream of their confluence.

The Lower Pleistocene deposits of Rhine, Meuse and the Belgian rivers show a clear interrelationship. They are bounded by two regional wellmapable unconformities and are preserved in from west to east changing lithostratigraphical sequences. Revision of the lithostratigraphical schemes in Germany and the Netherlands and the better defined lithostratigraphical position of Meuse deposits in Germany now strongly constrain the correlation of the various fluvial deposits. As a result existing reconstructions of the fluvial deposition and tectonic history of the southern Roer Valley Graben can be evaluated and re-adjusted.

It is concluded that the main course of the Meuse was aligned through the so-called East Meuse valley during the larger part of the Early Pleistocene. Available pollen data do not conflict with this conclusion. At the same time the Rhine ceased to enter the southern part of the Roer Valley Graben. Instead, the Meuse accumulated here a series of deposits derived from the East-Meuse valley. Simultaneously, the Belgian rivers filled available accommodation space in the Roer Valley Graben of the southern Netherlands. The conclusions are based primarily on the revised lithostratigraphical framework. In general they simplify the picture of fluvial and tectonic behaviour of the area.

Keywords: Lower Rhine Embayment, Rhine, Meuse, palaeogeography, lithostratigraphy, heavy minerals, subsidence

\section{Introduction}

Late Pliocene and Early Pleistocene fluvial sedimentation in the southern Roer Valley Graben (Ruhr-Scholle) originates from three main river systems: Rhine, Meuse and smaller rivers draining the central and northern part of Belgium (Fig. 1). Complex tectonics in the area and poor age control on the deposits from this time-slice make that it remains problematic to derive the architectural interrelationships of the deposits from these three river systems, even after nearly a century of geological research (Tesch, 1908; Fliegel \& Stoller, 1910; Wunstorf \& Fliegel, 1910; Kurtz, 1913; Tesch, 1908; Brueren, 1945; Zonneveld, 1949, 1955, 1957; Breddin, 1955; Kuyl, 1980; Felder \& Bosch, 1989; Zagwijn, 1985, 1989; Van den Berg, 1989; Juvigné \& Renard, 1992; Klostermann, 1992; Van den Berg \& van Hoof, 2001; Boenigk, 1978a, 2002).

A major problem is the use of a stratigraphy based upon a gradual intermingling of bio-, chrono-, morpho-, and lithostratigraphical criteria through the last century. An example of this is the inclusion of easily differentiated Meuse deposits upstream 


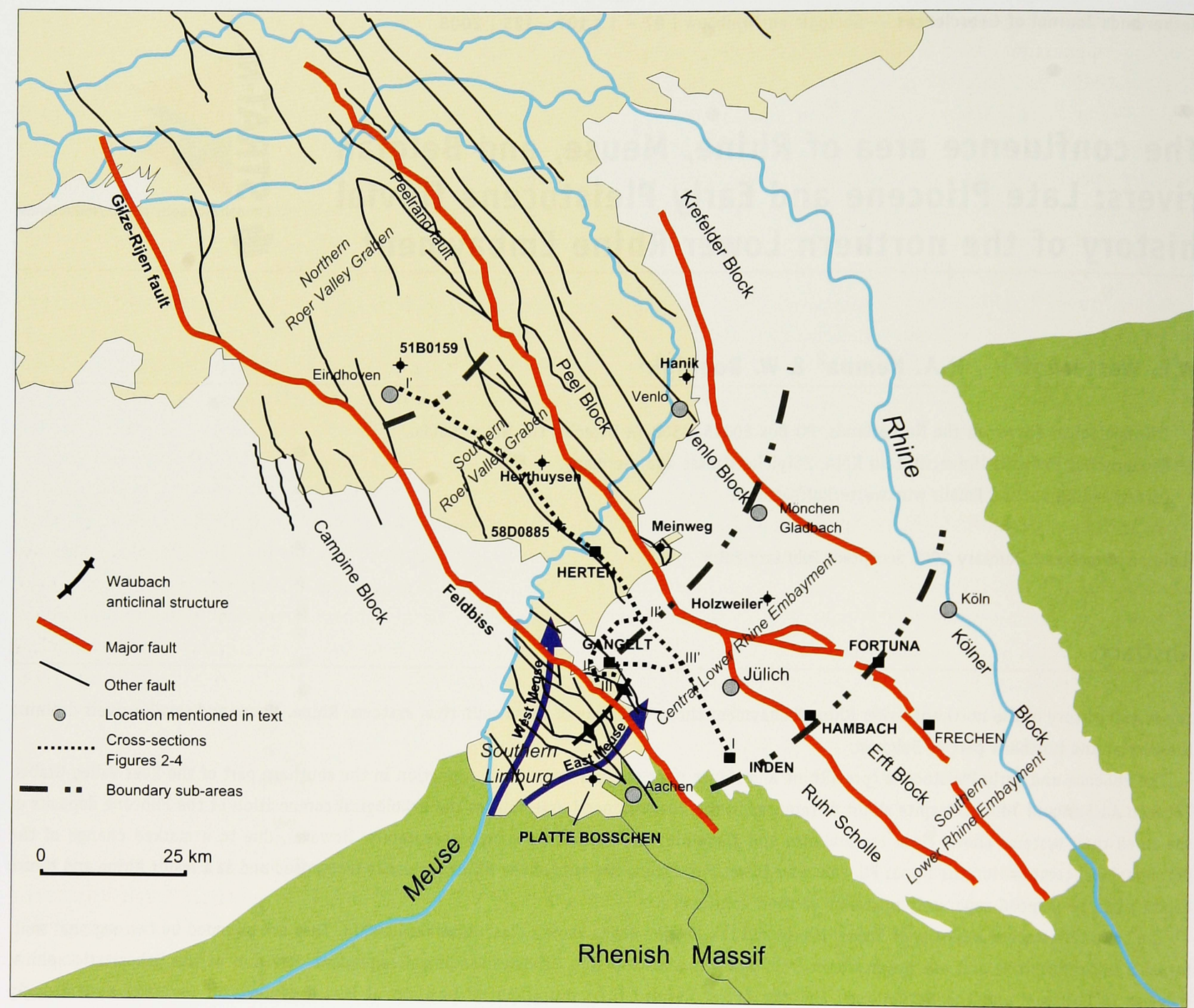

Fig. 1. Main tectonic structures of the Lower Rhine Embayment and SE Netherlands. Cross-sections and locations mentioned in the text are indicated.

in the same formation as those downstream of the confluence with the Rhine which have mixed Rhine-Meuse petrographical composition (Tegelen Formation cf., Doppert et al., 1975). Another example concerns the base of the Lower Pleistocene deposits of Belgian river sequences in the Netherlands (Kedichem Formation, cf. Doppert et al., 1975; currently part of the Stramproy Formation, cf. Westerhoff et al., 2003). A post-Tiglian age of its base has long been presumed, throughout the distribution area of these deposits. However, rigid use of the base of the Stramproy Formation as a regional significant time marker results in unrealistically high subsidence rates for the southern Roer Valley Graben (RVG) in the Netherlands. As is demonstrated already by their names, lithostratigraphical units in Germany are strongly determined by their (assumed) age or the correlation with the morphostratigraphy of the river terrace surfaces. Because of the poor age control in the Plio-Pleistocene, this automatically leads to confusing interpretations. Consequently, a comprehensive and satisfactory cross-border correlation is still lacking.
In this paper we attempt to correlate the recently revised lithostratigraphical schemes (Kemna, 2005; Boenigk \& Frechen, 2006; Westerhoff et al., 2003) and provenance data from Germany and the Netherlands. In order to achieve this we focus on the following questions:

- Is there a relation between the Early Pleistocene disappearance of the Rhine from the southern RVG and the development of an extensive body of Meuse deposits in Germany in the prolongation of the East Meuse valley?

Can we correlate the development of these Meuse deposits in the southern RVG in Germany with the up to $90 \mathrm{~m}$ thick sequence of fluvial deposits in the Dutch part of the RVG that were deposited by rivers draining the central and northern part of Belgium?

Do more strictly applied lithostratigraphical concepts improve reconstruction of the geological history of the southern RVG, and what is the significance for the earlier applied age models? 
By detailed provenance studies (i.e. sediment petrography) and the application of new lithostratigraphical concepts (Kemna, 2005; Westerhoff et al., 2003; Westerhoff et al. in prep.; Weerts et al., 2003) we have been able to map the deposits of the three fluvial systems. The revised stratigraphical position of the various fluvial sequences is discussed with respect to their traditionally assumed ages as interpreted from associated palynology. This resulted in an improved palaeogeographical concept of the fluvial history of the Lower Rhine Embayment (LRE) and the southern RVG, which has been strongly controlled by the neotectonic movements of the Roer Valley Rift system.

\section{Geological setting}

The Lower Rhine Embayment (LRE) forms the most southeasterly encroachment of the North Sea Basin and determines the subsurface structure of Nordrhein-Westfalen and the adjacent parts of the SE Netherlands. The relatively subsiding LRE is bounded to the south and east by Palaeozoic rocks of the Rhenish Massif (Fig. 1). The main faults show a SE-NW orientation. The tectonic history of the area is dominated by an approximate NW-SE horizontally orientated stress pattern which results in a subsurface structure that is dominated by NE-SW extension. The LRE forms part of the European Rift System (Ziegler, 1994; Geluk et al., 1994; Michon et al, 2003; Van Balen et al., 2005). The Roer Valley Graben (RVG) is the main tectonic feature of this rift system in the LRE and is bounded by the Campine Block to the west and the Peel and Erft Blocks to the east (Geluk, 1994; Klostermann, 1983). The RVG is confined by major faults systems, i.e. the Feldbiss fault zone and Gilze Rijen fault to the south and the Peelrand fault to the north (Fig. 1). Its present phase of extension has been ongoing since the Late Oligocene and resulted in up to 1200 $\mathrm{m}$ of subsidence in the RVG, while the Peel Block subsided only some $200 \mathrm{~m}$ (Geluk, 1994).

During the Neogene, marine sedimentation prevailed in the greater part of the LRE. Thick brown coal seams developed at the south-eastern part of the embayment. Fluvial deposition began at the end of the Miocene and progressed gradually westwards through time. Its provenance reveals uplift and erosion of the Rhenish Massif immediately to the south and southeast. Late Miocene and Early Pliocene fluvial sediments in the LRE were deposited by a (pre-)Rhine drainage system (Gliese \& Hager, 1978; Boenigk, 1978a, 1978b). The west to northwest progradation of the fluvial to deltaic system of the Kieseloolite Formation has been determined by the interplay of tectonic and sea-level movements. As a result the coastline shifted concurrently in the same direction and by the end of the Pliocene the southern part of the Netherlands was dominated by fluvial deposition (Zagwijn, 1989).

The Meuse incised the so-called East Meuse valley in southern Limburg during the Pliocene and Early Pleistocene
(Brueren, 1945; Zonneveld, 1949; Kuyl, 1980; Juvigné \& Renard, 1992; Van den Berg, 1994) and was confluent with the Rhine in the RVG/Rurscholle near Jülich. The Lower Pleistocene deposits of the Belgian rivers show thick accumulations in the southern RVG. This indicates a northeasterly orientated drainage pattern crossing the Campine block in the eastern part of Belgium (Tavernier \& De Moor, 1974; Macar, 1976). It should be noted that the Rupel and Campine cuestas in Belgium did not exist at that time (De Ploey, 1961; Vandenberghe \& De Smedt, 1978; Kasse, 1988).

\section{Petrography and lithostratigraphy as primary tool for data interpretation}

\section{Introduction}

This study advocates for mapping and palaeographical reconstructions an approach based on the lithostratigraphical discrimination, position and distribution patterns of fluvial deposits. Each identified unit is typified by its lithological and petrographical characteristics and therefore shows a close relationship to its provenance. In this section we describe the main characteristics of the deposits from the Rhine, Meuse and Belgian river systems.

\section{Pliocene fluvial deposits}

The larger part of the Pliocene Rhine-Meuse deposits is derived from the overburden of the Rhenish massif (Tesch, 1941). The deposits consist of quartz-rich sand and are typified by a predominant stable heavy mineral content. The latter mainly consists of minerals including: zircon, tourmaline, staurolite and some metamorphic minerals (e.g. the heavy mineral diagrams of Figs 2, 3, 4, and 6). Lithostratigraphically these whitecoloured sands are assigned as Kieseloolite Formation. Within the Kieseloolite Formation deposits of the Rhine, Meuse and the Belgian rivers cannot be mapped separately. Lithologically these deposits show a close resemblance because their sources are found in the deeply weathered overburden of the Rhenish Massif, Ardennes and the marine Tertiary deposits of Belgium. The influence of the Meuse however, can sometimes be recognised in the heavy-mineral spectra by an increase of coarse-grained stable heavy minerals, such as the metamorphic minerals, within the total heavy mineral assemblage.

South of the Feldbiss fault zone in southern Limburg (Fig. 1) some small remnants of Pliocene Meuse deposits occur as eroded terrace accumulations (Felder \& Bosch, 1989). The relative contribution from the Belgian rivers to the Kieseloolite Formation is not known and probably rather limited. However, it seems plausible that along the western distribution limit of the Kieseloolite Formation part of the deposits is supplied by in central Belgium originating rivers (Kasse, 1990; Van den Berg 1994, Vandenberghe et al., 2005). 


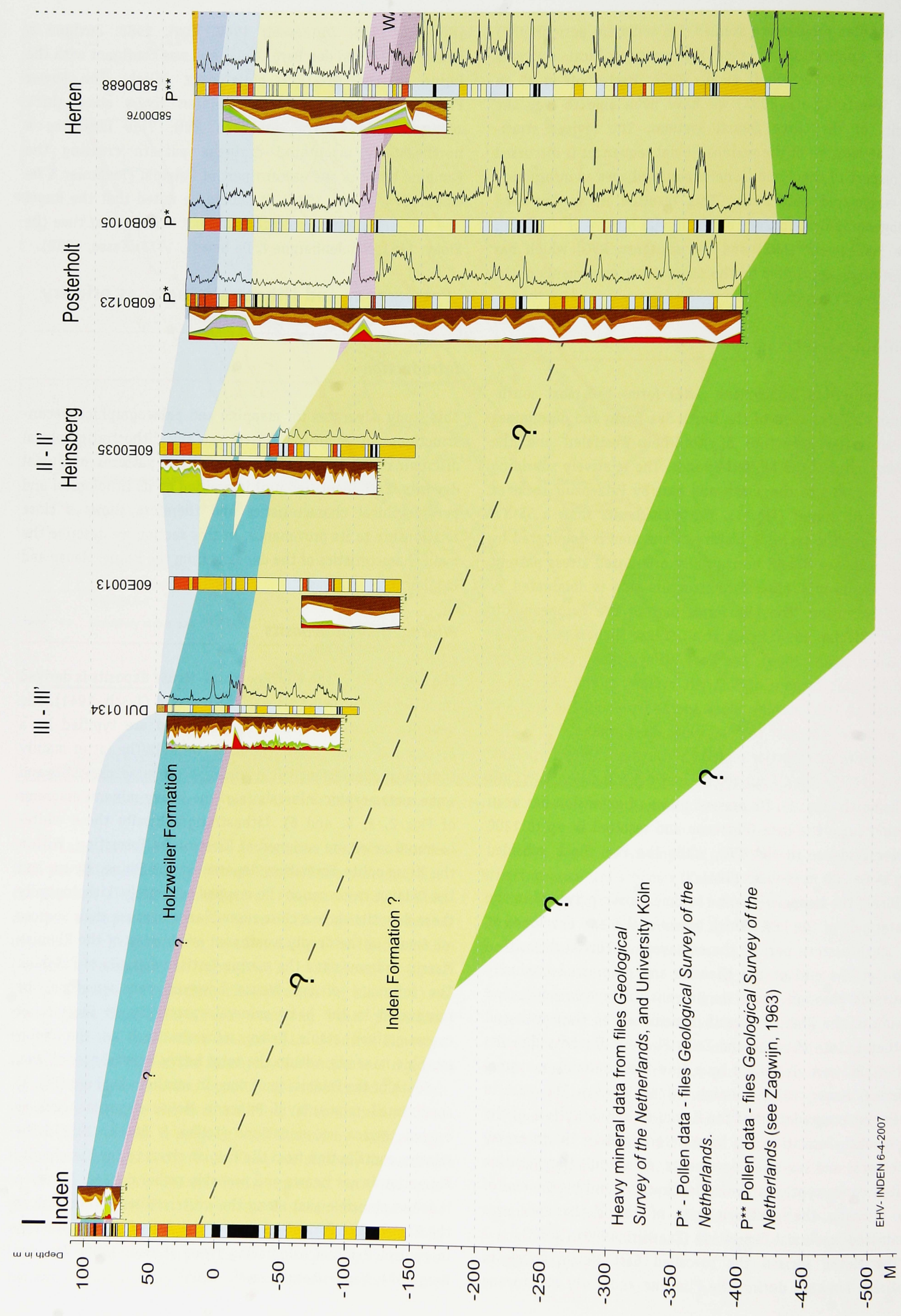




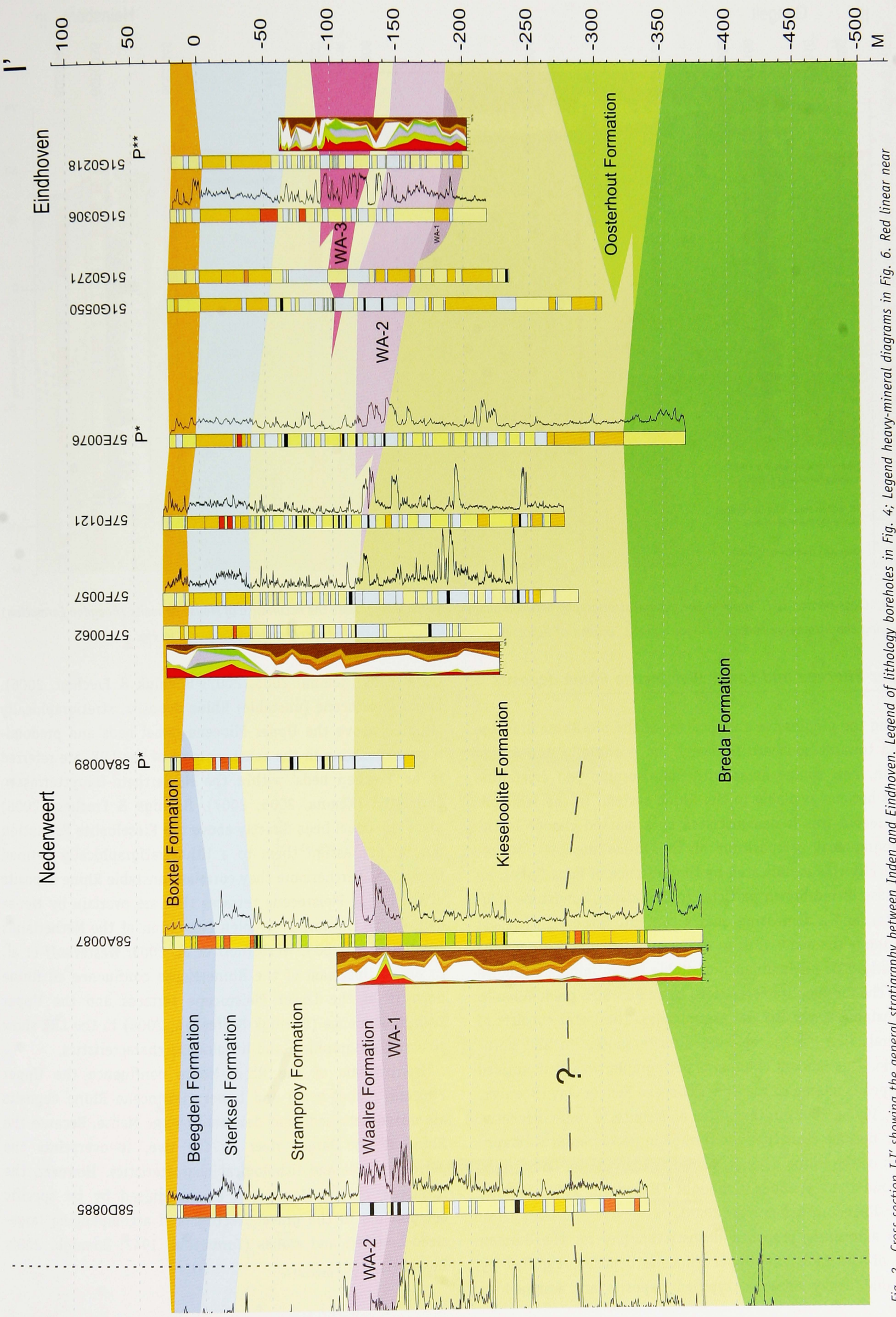

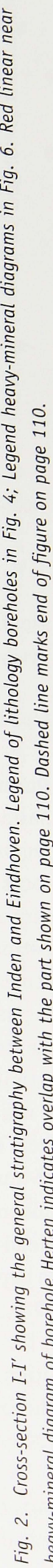


II Gangelt

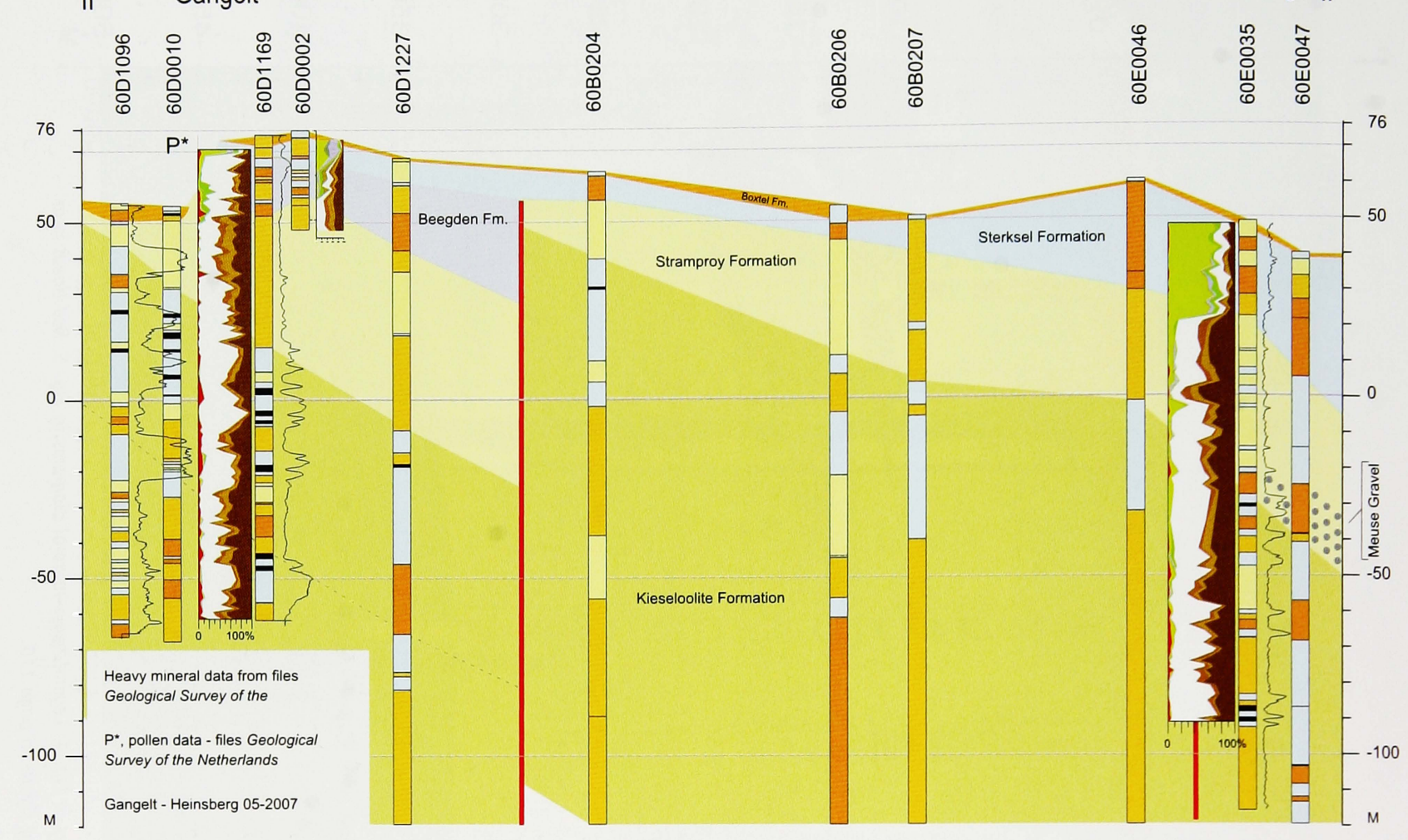

Fig. 3. Cross-section II-II' showing the general stratigraphy between Gangelt and Heinsberg. Note the occurrence of Meuse deposits (Beegden Formation) overlying the Stramproy Formation near Gangelt. Legend of lithology boreholes in Fig. 4; Legend heavy-mineral diagrams in Fig. 6.

\section{Upper Pliocene and Lower Pleistocene Rhine deposits}

During the progressive enlargement of the pre-Rhine drainage basin towards southern Germany and eventually, the Alpine region, new source areas with metamorphic and crystalline rocks became available to the Rhine system. In the sedimentary record this is demonstrated by a marked change in the petrographical composition of the Rhine deposits. Macroscopically this is indicated by the presence of mica-flakes, an increase of red-brown particles (e.g. feldspar, sandstone fragments), and a decreasing quartz content. However, the most striking is the major shift in heavy-mineral composition: from a nearly $90 \%$ predominance of stable heavy minerals (known from the Kieseloolite Formation) to an $80-90 \%$ predominance of unstable heavy-mineral assemblages. The latter consists of minerals like garnet, epidote, alterite/saussurite and hornblende. This marked change in petrography was first noticed in deposits related to the Upper Pliocene Reuver Clay (Boenigk, 1970, 1978a, 2002) in the border area south of Venlo. Recently, it has become clear that the change in petrographical composition of the Rhine deposits already began earlier in the Late Pliocene than previously thought (Hagedorn, 2004; Kemna, 2005; Hagedorn \& Boenigk, 2008).

In a recently proposed lithostratigraphy for the German part of the LRE, the Upper Pliocene deposits, typified by unstable heavy minerals typified deposits are assigned as
Oebel beds (Kemna, 2005, 2007; Boenigk \& Frechen, 2006). Lower Pleistocene (unstable) Rhine deposits, stratigraphically situated above the Upper Pliocene Oebel beds and predominantly occurring in the southern part of the LRE, are referred to as 'Frechen beds' within the Niederrhein-Hauptterrassen Formation (Kemna, 2005, 2007). Boenigk \& Frechen (2006) place the 0ebel beds directly above the Kieseloolite Formation but do not assign them to a lithostratigraphically defined formation. Furthermore they correlate unstable Rhine deposits of the Lower Pleistocene terraces that are overlain by Meuse deposits to the former Tegelen Formation of the Netherlands (Weerts et al. 2003, Westerhoff et al, 2003; Westerhoff et al. in prep). Upstream of the Rhine-Meuse confluence all Rhine deposits of the Lower Pleistocene terraces and the Upper Terrace Sequence (Boenigk \& Frechen, 2006) in the LRE show similar petrographical and lithological characteristics.

Downstream of the Rhine-Meuse confluence the Upper Pliocene (0ebel beds) and Lower Pleistocene Rhine deposits are mixed with sediment delivered by the Meuse. Because the Rhine is the larger river of the two, it overprints the petrographical and lithological characteristics. However, the influence of the Meuse can be recognised by its specific components in the gravel fraction and accompanying largesized boulders and stones (Zonneveld, 1947; Boenigk, 2002; Busschers, 2007). 


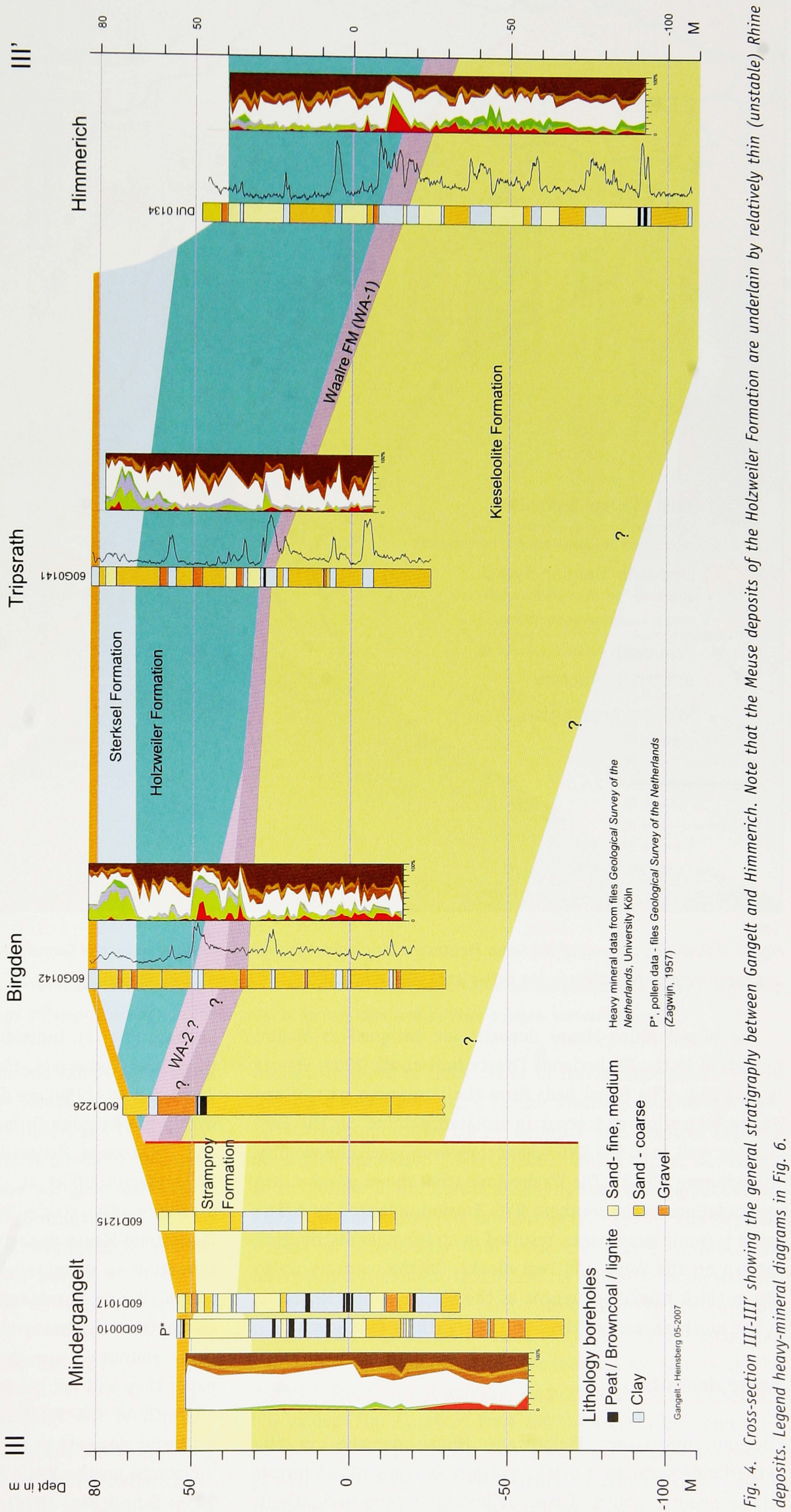




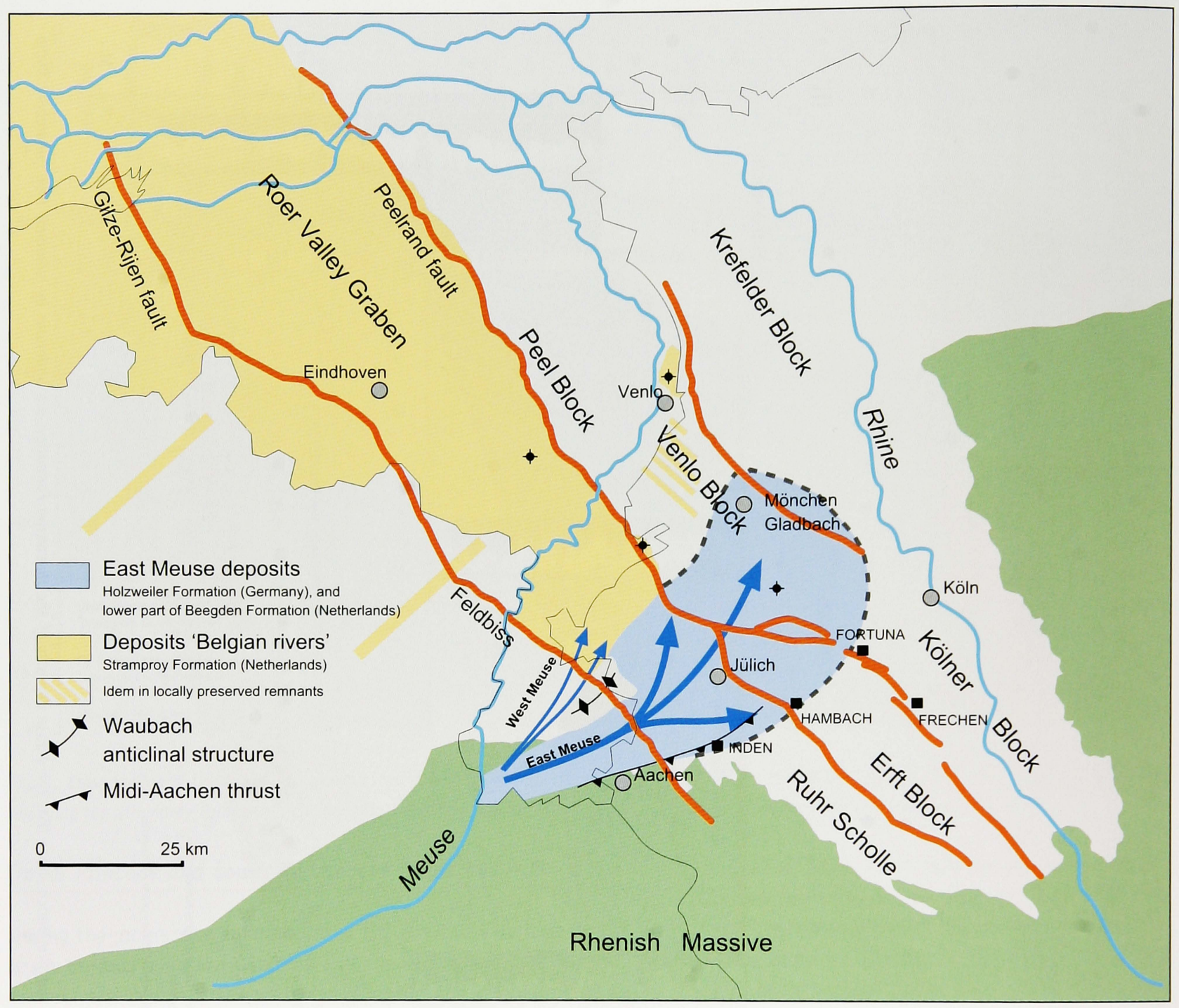

Fig. 5. Distribution patterns of the Lower Pleistocene Meuse deposits in the East Meuse valley and Germany (Boenigk, 1978a, 1979, 2002; Kemna 2005) and the Stramproy Formation in the Netherlands (Westerhoff et al., 2003; www.DINOloket.nl).

The mixed Rhine-Meuse deposits are assigned as Waalre Formation in the Netherlands (Westerhoff et al., 2003; Weerts et al, 2003). The 0ebel beds form the lowermost part of the Waalre Formation and occur in isolated patches on the Peel Block as well as in the RVG where they even reach the vicinity of Eindhoven (Fig.2). The Waalre Formation shows relative thin accumulations in the southern RVG. Erosion, initiated by differential tectonic movements, resulted in an irregular distribution pattern on the Venlo and Peel Blocks. On the contrary up to $100 \mathrm{~m}$ thick fluvial sequences of the Waalre Formation occur in the northern part of the RVG (i.e. north of Eindhoven).

\section{Meuse deposits}

Pliocene and Lower Pleistocene Meuse deposits in the Netherlands occur in a patchy pattern as remnants of former terrace deposits south of the Feldbiss fault zone in Southern
Limburg (Fig. 1). Individual easily mapped terrace deposits of the Meuse (Zonneveld, 1949, 1955, 1957; Felder \& Bosch, 1989; Van den Berg, 1989) are defined as morphostratigraphical units within the Beegden Formation. The latter includes all Pliocene and Pleistocene Meuse deposits in the Netherlands (Weerts, 2003; Westerhoff et al., 2003). The heavy-mineral content is predominantly stable for the Upper Pliocene and Lower Pleistocene Meuse deposits. However, in the upper part of the formation an increase of unstable minerals can be seen. The typical Vosges-hornblende and chloritoid then form notable elements in the heavy-mineral spectra (Zonneveld, 1947). As these younger Meuse deposits are beyond the scope of this paper they will not be described in more detail.

North of the Feldbiss fault zone the Meuse has formed extensive deposits in the German part of the RVG, on the Erft Block and on the Venlo Block (Fig. 1) (Kurtz, 1913; Breddin, 1955; Schnütgen, 1974). These characteristic Meuse deposits 


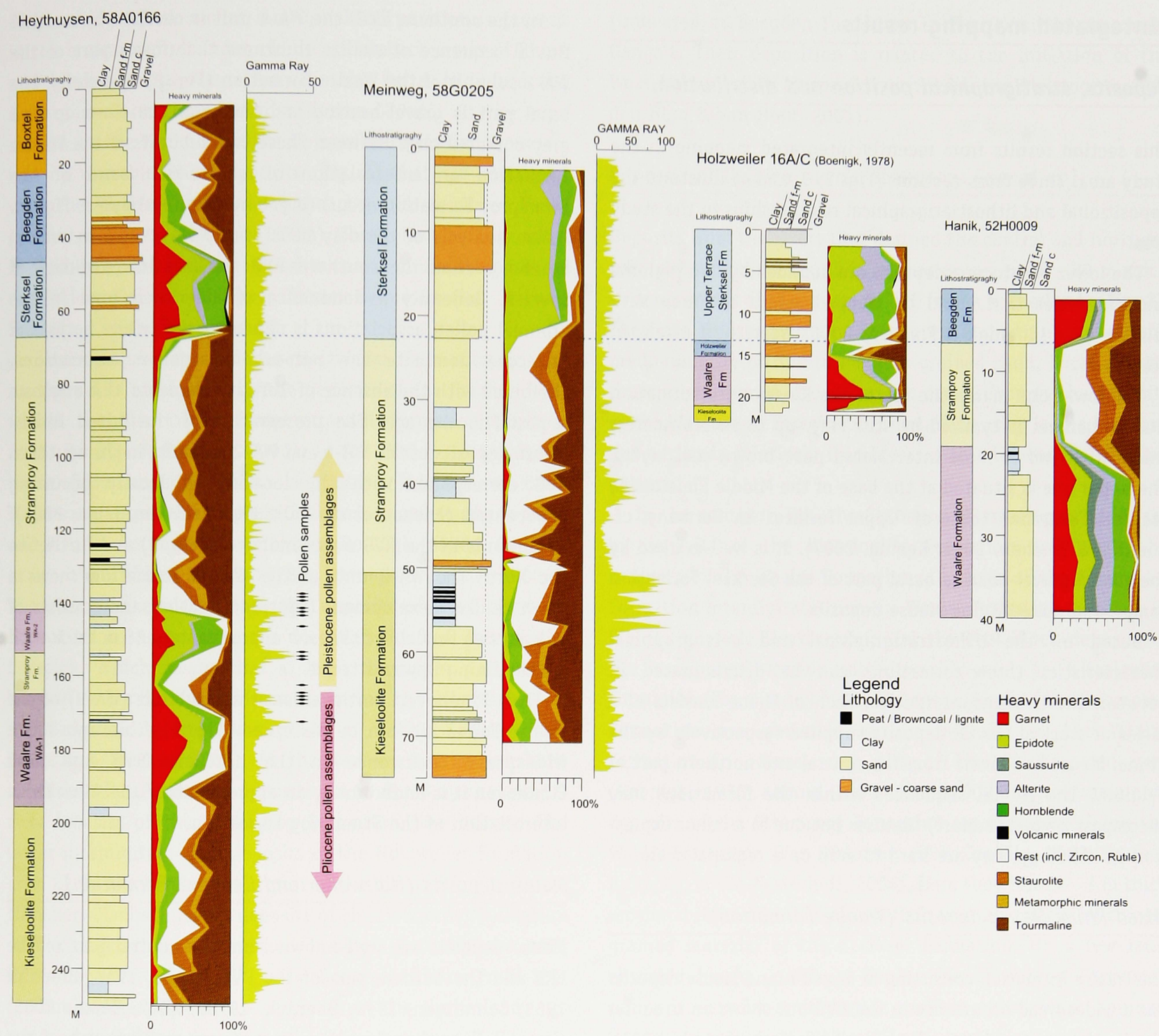

Fig. 6. Lithology, gamma-ray curves, heavy minerals and lithostratigraphy from 4 key sites in the study area (localities indicated in Fig. 1). Note that the Stramproy Formation may be underlain by different lithostratigraphical units of various ages and exhibits a highly variable thickness.

are typified by coarse-grained material and exhibit large-sized stones and boulders derived from the Meuse catchment. The heavy-mineral spectrum is dominantly stable, and typified by, among others staurolite, tourmaline and metamorphic minerals. In Germany these Meuse deposits are assigned lithostratigraphically to the Holzweiler Formation (Boenigk, 2002; Kemna, 2005; Boenigk \& Frechen 2006). The stratigraphic correlation with fluvial deposits downstream and age is a matter of discussion (see below).

\section{Deposits supplied by the rivers from central and northern Belgium}

A third source of Lower Pleistocene fluvial sediments in the SE Netherlands is formed by the northeastwards flowing rivers that drained the central and northern part of Belgium. They formed up to $90 \mathrm{~m}$ thick series of fluvial deposits on top of the Kieseloolite Formation in the southern part of the RVG. Lithostratigraphically these deposits are referred to the Stramproy Formation (Weerts, 2003; Westerhoff et al., 2003). In the former Dutch lithostratigraphy they formed part of the Kedichem Formation (cf. Doppert et al., 1975). The deposits consist of quartz-rich sand with low gravel content. The heavy-mineral content is dominantly stable with tourmaline, metamorphic minerals and staurolite (e.g. borehole Heythuysen, Fig. 6). As a result of the lack of feldspar, clay and other K-bearing minerals the gamma ray curves of the deposits from the Stramproy Formation show characteristic low values (Fig. 2). Apart from the thick accumulation in the southern RVG, the Stramproy Formation occurs in patchy patterns on the Peel and Venlo Blocks. In the northern part of the RVG it is widespread above the Waalre Formation. 


\section{Integrated mapping results}

\section{Deposits, stratigraphical position and distribution.}

This section results from recently integrated mapping in the study area. Three cross-sections (Figs 2, 3, and 4) illustrate the depositional and lithostratigraphical relationships in the study area.

The lower Pleistocene deposits are bounded by two regional unconformities that could be mapped across the area with relative ease (Boenigk \& Frechen, 2006; Westerhoff et al., in prep.).

The lower one marks the top of the Kieseloolite Formation that in general is typified by stiff clay, up to several meters thick, with two or more intercalated peat/brown coal layers. The upper one is situated at the base of the Middle Pleistocene Sterksel Formation (base of 'Upper Terraces' in Germany, cf. Boenigk \& Frechen, 2006; Kemna, 2007). It is well-marked by the coarse gravel-bearing basal part of the Sterksel Formation comprising mixed Rhine-Meuse deposits.

Based on the lithostratigraphical and petrographical characteristics three formations can be discriminated in between the two unconformities. Each of them consists of a series of stacked fluvial deposits supplied respectively by the Rhine, Meuse and rivers from the central and northern part of Belgium. The fluvial sequences within the formations may encompass several (minor?) hiatuses but due to a minor expression in lithology they are hard to map on a regional scale.

\section{Mixed Rhine-Meuse deposits (Waalre Formation)}

The Waalre Formation consisting of mixed Rhine-Meuse deposits has a widespread occurrence in the RVG but shows an irregular distribution pattern on the Peel Block (Westerhoff et al., 2003).

As shown in cross-section I-I' the deposits of the Waalre Formation can be subdivided into three different subunits, respectively: WA-1, WA-2, and WA-3 (Fig. 2).

The lowermost unit (WA-1) occurs in the tectonically deepest parts of the RVG (Fig. 2) and consists of 20 - 25 m thick fluvial deposits that show a clear fining upward trend (gravel at the base and clay with intercalated peat beds at the top). As a result of the lithological resemblance, the heavy-mineral assemblage, the lithostratigraphical position and the presence of 'Tertiary elements' in the pollen content of the clay beds (e.g. borehole Heythuysen, Fig. 6) the unit is correlated with the Oebel beds in Germany. Upstream in the RVG and on the Peel Block, south of Venlo, the Oebel beds are well-known from the open cast brown-coal pits near Inden and Hambach (Kemna, 2005), and from the Brachterwald area (Boenigk, 1970, 2002; Kemna, 2005; Westerhoff, 2004; Kemna \& Westerhoff, 2007). The WA-1 unit can also occur in more or less isolated spots on the fault blocks just north of the Feldbiss fault zone (e.g. Fig. 4).
In the southern RVG, the WA-1 unit is overlain by another fluvial sequence of similar thickness that forms part of the WA-2 subunit of the Waalre Formation (Fig. 2). Generally, the basal part is gravel-bearing and the sequence fines up into grey-coloured clay. Between these two subunits of the Waalre Formation an intercalation of quartz-rich sand of the Stramproy Formation occurs (e.g. borehole Heythuysen, Fig. 6). Pollen analysis of the clay beds of the WA-2 unit in several boreholes from the southern RVG shows a low diversity of species. Generally a dominance of alder and pine in the arboreal pollen associations is characteristic, while herbs and Ericaceae dominate the non-arboreal pollen associations. Combined with the absence of 'Tertiary elements' this suggests a post-Pliocene age. The preservation of the mixed RhineMeuse deposits of the WA- 1 and WA-2 subunits in the southern RVG corresponds with the location of locally occurring depocentres (Michon et al, 2003; Michon \& Van Balen, 2005). Northwards in the RVG near Eindhoven (Fig. 2) and further to the North the WA-2 unit of the Waalre Formation shows a much thicker development (up to $40-50 \mathrm{~m}$ ) and consists of at least two fluvial cycles, each approximately $25 \mathrm{~m}$ thick with a clear fining-upwards trend.

From Eindhoven northwards a third subunit (WA-3) of the Waalre Formation can be discerned (Fig. 2). This unit has a widespread occurrence in the northern RVG and near Eindhoven it is underlain by an approximately $15-20 \mathrm{~m}$ thick intercalation of the Stramproy Formation.

\section{Meuse deposits (Holzweiler and Beegden Formation).}

Meuse deposits are well-known from the central part of the LRE and the German part of the RVG (Kurtz, 1913; Breddin, 1955; Schnütgen, 1974; Boenigk, 1978a, 2002; Kemna 2005) (Fig. 1). Here they form the downstream continuation of the Meuse deposits formed in the East Meuse valley in Southern Limburg (Fig. 5). Within the central LRE these Meuse deposits, with their typical coarse gravel, stones and blocks, can be traced over the Erft and Venlo Blocks towards the vicinity of Mönchen-Gladbach (Kurtz, 1913; Schnütgen, 1974; Boenigk, 1978a; Kemna, 2005). Recently the Meuse deposits in Germany were assigned to the Holzweiler Formation (Boenigk, 2002). They consist of coarse-grained, light-coloured gravel, sand and locally occurring lenses of clay. The gravel fraction is typified by high percentages of quartz (up to 60\%) and flint (up to 20 $\%$ ) while the heavy-mineral content is generally dominated by stable associations (Boenigk, 2002, Kemna, 2005). Apart from this, the lithological and petrographical characteristics of the formation are also clearly reflected by the low values of the gamma-ray curves (Fig. 4).

In the German part of the RVG and in the central part of the LRE the Holzweiler Formation is underlain by the unstable Rhine deposits of the 0ebel Beds (WA-1) and probably also by a part of the WA-2 unit of the Waalre Formation (e.g. borehole 
Birgden, Fig. 4). A similar stratigraphical position is present at the brown coal pit Inden, while at Hambach a mix of Rhine and local deposits occurs between the 0ebel beds and the Holzweiler Formation deposits (Kemna, 2005). At the type section on the Venlo Block the Holzweiler Formation is underlain by unstable Rhine deposits (Fig. 6) that are correlated with the Waalre Formation of the clay pits south of Venlo (Schnütgen, 1974; Boenigk, 1978a). The Holzweiler Formation is overlain by the well-recognisable coarse-grained deposits of the Middle Pleistocene Upper Terrace Sequence (i.e. Sterksel Formation in the Netherlands).

Lateral equivalents of the Holzweiler Formation in the southern LRE are formed by the deposits of the Frechen beds within the Niederrhein Hauptterrassen Formation (Kemna, 2005; Boenigk \& Frechen, 2006). In the fine-grained parts of these fully unstable Rhine deposits a number of Early Pleistocene interglacial deposits is found, known as the Fortuna and Frechen Interglacial complexes (Boenigk, 1978a, Boenigk et al., 1979; Urban 1978a, 1978b; Boenigk \& Frechen, 2006). There is good evidence that the deposits of the Holzweiler Formation correlate with the so-called Frechen Interglacial Complex. Which means that at least the upper part of the Holzweiler Formation was formed during the second half of the Early Pleistocene (Boenigk et al., 1979; Kemna 2005; Boenigk \& Frechen 2006). At the western distribution limit the Holzweiler Formation deposits are bounded by the quartzrich deposits of the Stramproy Formation (see below). The latter interdigitate with deposits of the Holzweiler Formation (Fig. 2). In the northernmost part of the distribution area near Mönchen-Gladbach Meuse deposits of the Holzweiler Formation with characteristic large sized boulders interdigitate with Rhine deposits (Schnütgen, 1974; Boenigk 1978a - Profil 18).

Unmixed mapable Meuse deposits in the Netherlands are assigned to the Beegden Formation which contains all Pliocene and Pleistocene deposits of the Meuse in the Netherlands (Weerts, 2003; Westerhoff et al., 2003). In southern Limburg the Meuse accumulated a whole flight of terrace accumulations south of the Feldbiss fault zone (Brueren, 1945; Van Straaten, 1945; Zonneveld, 1949, 1955, 1957; Kuyl, 1980; Felder \& Bosch, 1989; Van den Berg, 1989; Juvigné \& Renard, 1992; Van den Berg, 1994; Van den Berg \& Van Hoof, 2001). Within this sequence of terraces a major subdivision discriminates between an older series as the East Meuse valley was downcutting and a younger one tied to the West Meuse valley (Felder \& Bosch, 1989; Van den Berg, 1989; Juvigné \& Renard, 1992; Van den Berg, 1994; Van den Berg \& van Hoof, 2001).

The Simpelveld Terraces form the last terrace accumulation fully tied to the East Meuse valley (Felder \& Bosch, 1989) while the Margraten Terrace is seen as intermediate between the two series (Van den Berg, 1989; Van den Berg \& van Hoof 2001). The older series continues into the Holzweiler Formation. Deposits of the stratigraphical lowermost terraces of the West Meuse series overlie the Stramproy Formation (indicated as Beegden Formation in Fig. 3) in the area near Gangelt. Their deposition is related to the initiation of the West-Meuse valley at some time within the Pleistocene (Van den Berg \& Van Hoof, 2001).

\section{Deposits of Belgian rivers (Stramproy Formation)}

Deposits from the rivers that drained the central and northern part of Belgium are found in sequences up to 80 - $90 \mathrm{~m}$ thick in depocentres of the southern RVG in the Netherlands (Fig. 2). They are assigned to the Stramproy Formation and consist predominantly of fine to medium-grained sand. Locally, some fine-grained gravel also occurs. In comparison to the deposits of the Waalre and Kieseloolite Formations, clay is less frequent and occurs in relatively thin layers with a limited distribution pattern.

In the southern RVG the Stramproy Formation is underlain by deposits of the Kieseloolite Formation and locally by deposits of the Waalre Formation. Deposits of the Stramproy Formation interdigitate with the Waalre Formation (e.g. Fig. 2; Fig. 6, borehole Heythuysen). On the Peel Block deposits of the Stramproy Formation unconformably overly the Kieseloolite Formation (Fig. 6, borehole at Meinweg). Signs of the Stramproy Formation are observed within deposits of the Waalre Formation in several clay pits of the Brachterwald area (Boenigk, 1970; Kemna, 2005, 2007, 2008). In the same area deposits of the Stramproy Formation are found overlying the Waalre Formation (Van Straaten, 1956; Zagwijn, 1960: Kasse \& Bohncke, 2001; Westerhoff, 2004). Here they form 2 - $3 \mathrm{~m}$ thick erosional remnants that are overlain unconformably by coarsegrained material of the Sterksel Formation. On a few fault bounded blocks, north of Venlo, the Stramproy Formation occurs in a similar stratigraphic position and shows an approximate thickness of $15-20 \mathrm{~m}$ (Fig. 6, borehole Hanik).

In Germany near Heinsberg, the fine-grained deposits of the Stramproy Formation interdigitate with the coarse-grained material of the Holzweiler Formation; an observation already made by Breddin (1955) (Fig. 2). Mapping results show that the Stramproy Formation occurs also on the tectonic blocks just north of the Feldbiss (Fig. 3). Here it rests discordantly on the Kieseloolite Formation and is overlain by the Sterksel Formation (Westerhoff et al., in prep; Vandenberghe et al., 2005). An exception is the intercalation of deposits of the Beegden Formation in a restricted area near Gangelt (Fig. 3).

\section{Stratigraphical sequences in the Roer Valley Graben}

Between the two major unconformities the deposits of the three main river systems show a complex interrelationship that changes from NW to SE (Fig. 7). The top of the Oebel beds or WA-1 marks the lower unconformity and can be traced in all parts of the RVG and on the Peel Block in the Netherlands and far upstream in Germany. 


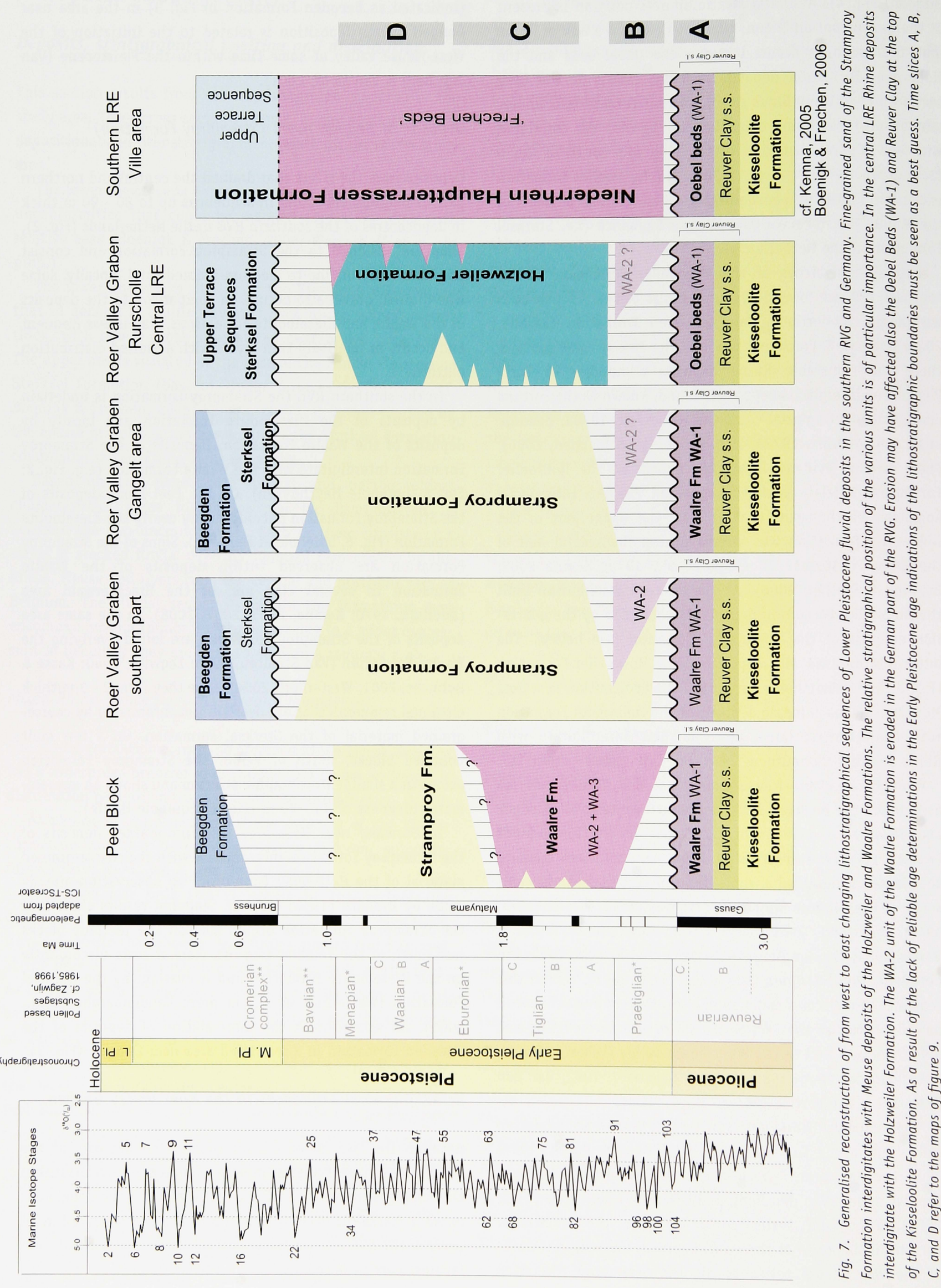


The overlying unstable Rhine deposits of the WA-2 unit occur only in the southern part of the RVG in the Netherlands and are tied to the regional depocentres. Part of the deposits of the Waalre Formation at Birgden (Fig. 4) possibly represents the same unit. However, the lack of pollen or other microfossil evidence prevents confirmation of this correlation. The Heythuysen borehole (Fig. 6) shows that stable deposits of the Stramproy Formation occur between the WA-1 and WA-2 units. The presence of deposits that form part of the WA-2 unit in the southern RVG indicates that unstable Rhine deposits were formed in the RVG after the deposition of the 0ebel beds. Their limited distribution at present is the result of later erosion. The intercalation of deposits from the Stramproy Formation (e.g. Fig. 6; borehole Heythuysen) indicates that rivers that originated in the central part of Belgium deposited across the whole Rhine alluvial plain throughout the stratigraphic interval discussed. As a result of tectonic movement and subsequent erosion, the deposits of the Stramproy Formation rest directly on the Kieseloolite Formation in a zone adjacent to the Feldbiss fault zone (Figs 3,4).

The stratigraphical sequence in the Central Lower Rhine Embayment shows a different picture. Here Meuse deposits occur in a similar stratigraphical position as the Stramproy Formation in the southern RVG in the Netherlands. The lack of deposits belonging to the WA-2 unit of the Waalre Formation is probably the result of erosion: the unconformity marks a significant hiatus in the stratigraphical record between the Holzweiler Formation and the top of the Oebel beds. At its western distribution limit the Holzweiler Formation interdigitates with the Stramproy Formation (Fig. 2, near Heinsberg). This implies that, at least part, of the formations accumulated simultaneously. The lack of Rhine deposits in the same stratigraphical position in the southern RVG and central part of the LRE implies that the Rhine had abandoned this area at this time.

The top of the Stramproy Formation in the southern RVG is marked by the upper major unconformity of the Sterksel Formation (younger Upper Terrace Sequence in Germany, Boenigk \& Frechen, 2006). In a restricted area west of the Waubach anticlinal structure, pure Meuse deposits are found overlying the Stramproy Formation (Fig. 3). These Meuse deposits are correlated with the Sint Geertruid Terrace deposits (Felder \& Bosch, 1989; Van den Berg \& van Hoof, 2001), and form part of the terrace sequence of the West Meuse valley. In the Central Lower Rhine Embayment the transition from the Holzweiler Formation to the overlying deposits of the Upper Terrace Sequence is marked by an unconformity.

\section{Discussion}

\section{Deposits of the Meuse and age of the East Meuse valley abandonment}

The distribution and age of the Holzweiler Formation imply that the Meuse 'blocked' the RVG from receiving sediment of Rhine provenance during a substantial part of the Early Pleistocene. From the reconstruction of the fluvial history in the study area it seems that as soon as it entered the RVG the Meuse first formed a kind of alluvial fan deposit (Fig. 5, 7). At the same time the Rhine occupied a course on the Venlo Block (Boenigk, 1978b, 2002; Kemna 2005, 2007). Further eastward shifting of the Rhine facilitated the Meuse to lengthen its course further to the northeast on the Venlo Block.

Despite the longstanding recognition of widespread Meuse deposits in Germany, too little attention has been paid to the correlation with the terrace sequence of the East Meuse valley. The palaeovalley of the East Meuse is situated between the Midi Aachen thrust and the Waubach anticline (Van den Berg 1994; Van den Berg \& Van Hoof 2001) (Fig. 5). Its northern flank may have been formed as a result of reactivation of the Waubach anticline. Subsequently, the development of the terrace sequences of the West Meuse show a progressively north-westward migration of the river. However, preceding that development the Meuse incised and flowed in its eastern valley. The deposition of the East Meuse continued into the Holzweiler Formation in Germany. As the latter was formed during the larger part of the Early Pleistocene, the course of the Meuse through the East Meuse valley must have been active throughout the same time span.

Such a relatively prolonged period of deposition, well into the Early Pleistocene, contradicts the view of some authors that the Meuse abandoned the East Meuse valley at the end or in the middle part of the Tiglian Stage, approximately 1.8 or 2.1 Ma ago (Kuyl, 1980; Felder \& Bosch, 1989; Juvigné \& Renard, 1989; Van den Berg, 1994; Van den Berg \& van Hoof, 2001). Those ages confirm the age attributions to the Simpelveld and Margraten Terraces of the latter authors. The interpretation is based on pollen and palaeomagnetic information obtained from floodplain clay with peat at the top of the Simpelveld Terrace deposits, e.g. at the Platte Bosschen site (Fig. 1).

The by pine- and spruce-dominated pollen assemblages of the pollen diagram (Fig. 8) point to a late phase of an interglacial or interstadial in the Early Pleistocene. An attribution to a specific Early Pleistocene stratigraphical substage was not done (Zagwijn \& De Jong, 1963). Following the results from studies at Süsterseel (Zagwijn \& De Jong 1985), the diagram was reinterpreted as representing the Tiglian TC-6 pollen zone and thus could be placed in the final phase of the Tiglian $C$ Substage (Zagwijn, 1974; Kuyl, 1980). In a subsequent publication Van den Berg \& Van Hoof (2001) reinterpreted the diagram as representing part of the so-called Tiglian B Substage. 


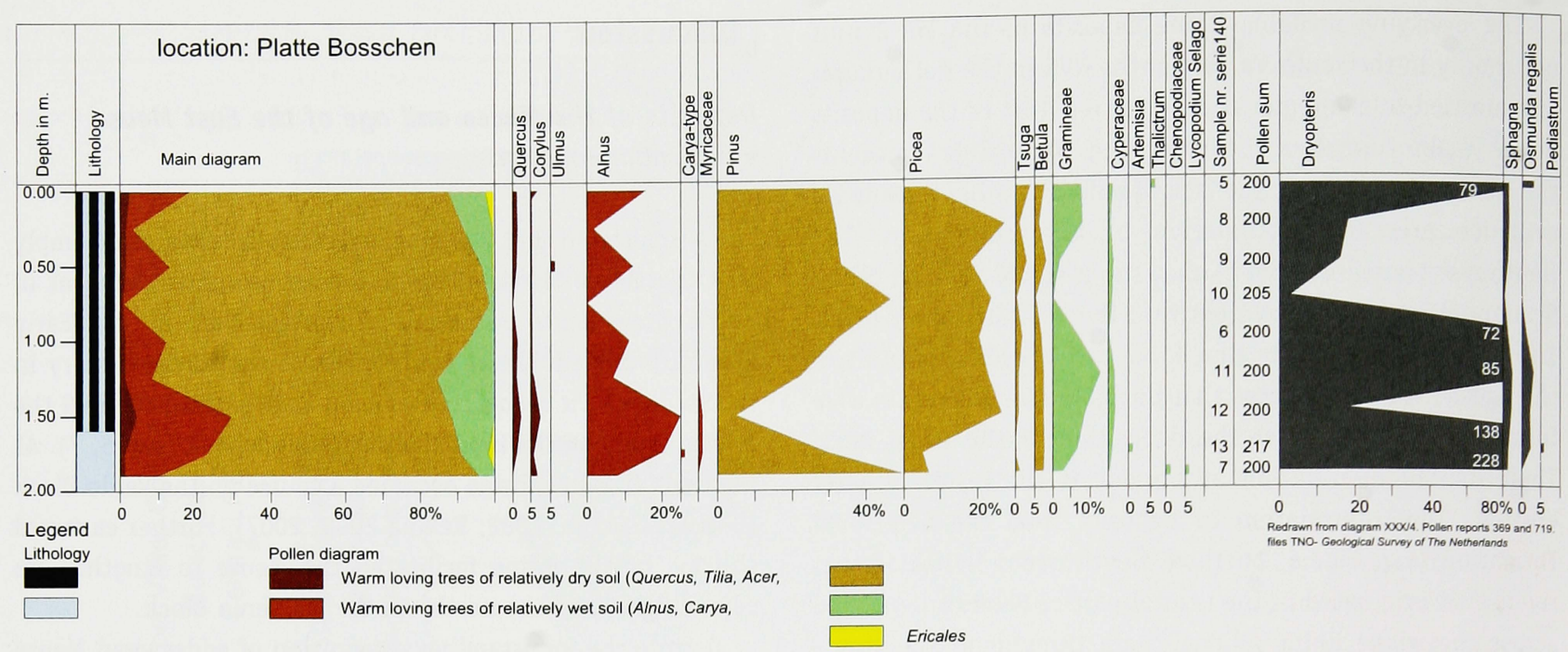

Fig. 8. Pollen diagram from the Platte Bosschen site (redrawn from the original diagram in an internal report from the Geological Survey of the Netherlands, cf. Zagwijn \& De Jong, 1963).

Palaeomagnetic measurements from the same sequence at Platte Bosschen (Fig. 1) show a normal to reversed polarity (Bruins, 1981; Van den Berg \& van Hoof, 2001) which should corresponds to the Réunion-Matuyama transition.

A closer examination of the pollen sequence from Platte Bosschen shows an assemblage dominated by alder pollen and fern spores, at the top of the floodplain clay (Fig. 8). This indicates a local environment that is typical of a claydominated floodplain. In the overlying peaty part of the sequence a combination of pine and spruce is dominant. Which in general may be related to the end phase of an interglacial or interstadial vegetation succession (Zagwijn, 1963, 1992). The presence of Tsuga is indicative of an Early Pleistocene-age, although this genus forms only a minor element in Early Pleistocene pollen spectra (Zagwijn \& De Jong, 1984). From these points we can conclude that the palynological and magnetic evidence from the Platte Bosschen site does not allow for a more precise positioning of the sequence other than somewhere in the Early Pleistocene during a normalreversed event.

Combining our observations with those of the age indications for the Holzweiler Formation in Germany it becomes quite clear that the Meuse continued to flow via the East Meuse valley until late in the Early Pleistocene. As a consequence the drainage pattern of the Rhine in the RVG and parts of the Erft and Venlo Blocks was hampered during the same period.

\section{Rhine abandonment of the southern Roer Valley Graben and the central part of the Lower Rhine Embayment}

Surprisingly, deposits from the largest river, the Rhine, are the least widespread in the southern RVG, for the larger part of the Early Pleistocene. For some reason the Rhine migrated away from the depocentres in the southern RVG. The preserved fluvial sequences show that when the Rhine abandoned the southern RVG, the delivery of sediment by the Belgian rivers continued infilling of the accommodation space created by subsidence. Simultaneously, Meuse deposits accumulated in the German part of the RVG and filled the area abandoned by the Rhine.

A post-Tiglian age of the base of the Belgian river deposits (Stramproy Formation, Westerhoff et al., 2003; formerly part of the Kedichem Formation, cf. Doppert et al., 1975) has long been presumed, but is just one within a range of possibilities. Many former reconstructions ignored the potential diachronous nature of its base. The Stramproy Formation is underlain by different lithostratigraphic units of various ages, the latter conditioned by the relative position on different tectonic blocks. More importantly, the formation interdigitates with the Waalre-, Beegden- and Holzweiler Formations and thus has no unique coeval basal contact throughout the area (Fig. 6). The intercalations indicate simultaneous deposition of material of Rhine, Meuse and Belgian provenance, for at least part of the time covered by the three formations. West of the study area, on the Campine Block it is demonstrated that deposition by the Belgian rivers (Stramproy Formation) took place already during the Tiglian and continued during the larger part of the Early Pleistocene (Kasse,1990).

Considering the situation mentioned above, it is worthwhile taking a closer look at the generally post-Tiglian base of the deposits of the Stramproy Formation. This age is based on the assumption that this formation spans deposits that are time-equivalent with the top of the Waalre Formation everywhere in its distribution area. Generally this age is interpreted as Late Tiglian to Early Eburonian (Zagwijn, 1960, 1963).

Indeed, there are localities where the Stramproy Formation directly overlies Late Tiglian deposits of the Waalre Formation (WA-3). This is especially the case in the northern RVG, 
(indicated in the uppermost right-hand corner in Fig. 2) and on the Peel Block near Venlo. Late Tiglian to Early Eburonian ages established for the base of the Stramproy Formation in those areas have been traditionally extrapolated throughout the whole distribution area. To the south and west into the RVG, however, there are sites where the Stramproy Formation overlies older parts of the Waalre Formation. It is especially so in the southern RVG, where it overlies the relatively thin deposits of the WA-2 subunit (Fig. 2). Here sediment supply by the Belgian rivers replaced delivery by the Rhine as soon as the latter abandoned that area. Further north in the RVG, where much thicker sequences of the Waalre Formation occur, the Stramproy Formation interfingers with deposits of the Waalre Formation (Fig. 2). The latter deposits must have been delivered by a coeval Rhine course that followed a pathway across the Peel Block from the area near Venlo to the west.

Field observations from the pits near Tegelen south of Venlo (Fig. 1) have demonstrated that the Stramproy Formation on top of the upper clay of the Waalre Formation has an average thickness of approximate 2 - $3 \mathrm{~m}$ (Van Straaten, 1956; Van der Vlerk \& Florschütz, 1953; Zagwijn, 1963; Kasse \& Bohncke, 2001; Westerhoff, 2004). The deposits show a threefold subdivision based on two levels of periglacial phenomena and an intercalated humic soil horizon. This observation forms the basis for the post-Tiglian subdivision of the Early Pleistocene into the Eburonian, Waalian and Menapian stages (Zagwijn, 1960). Here we encounter a general problem that arises from the study of easily accessible deposits in exposures situated on a horst like the Peel Block. These sections favour detailed studies of sequences that span relative brief lengths of time. However, when it is assumed that the horst sections are condensed, then they may represent an equal amount of time compared to the much thicker sequences preserved in the adjacent subsiding areas. Subsequently, the interpretation and concepts obtained from the horst areas can be extrapolated to the much thicker graben sequences. However, such an interpretation does not correspond with the current ideas on fluvial sedimentology (a.o. Miall, 1996; Weerts, 1996; Berendsen \& Stouthamer, 2002; Bridge, 2003). The latter imply that horst sequences preserve fragmentary intervals of fluvial activity separated by long hiatuses. The implication of these observations therefore is that palynology-based age attributions determined through correlation of type sections located on the Peel Block to RVG sequences relies on a potentially incomplete record. Previous subdivisions of the stratigraphical record in this area underestimated the innate fragmentary character of these fluvial sequences. Consequently, we conclude that the pollen stratigraphy from the Horst area (Peel Block) is not representative for the entire sequence in the Graben and is too incomplete to be suitable as a type-area for a regional chronostratigraphical scheme, notwithstanding that it does provide excellent but discontinuous detail of individual Early Pleistocene palaeoenvironments.
These considerations and the stratigraphical relationships between the Stramproy, Waalre and Holzweiler Formations justify a diachronous base of the Stramproy Formation. In the southern RVG this base is beyond the level of the intercalation of the Stramproy Formation with the Waalre Formation near Eindhoven (Fig. 2) and predates the top of the WA-3 unit. Based on palyno-stratigraphical correlations the latter is attributed to an early part of the Eburonian Substage (Zagwijn, 1963). So, the onset of the deposition of the Belgian rivers in the southern RVG is well beyond that age. This also means that the Rhine abandoned the southern RVG before the end of the Tiglian Substage.

\section{Tectonic framework}

Due to the uncertainties in the existing age models of the Pliocene to Early Pleistocene, a closer examination of the tectonic movements in the study area may serve as a subsidiary approach.

Subsidence in the RVG is mainly fault-controlled and shows decreasing rates from northwest to southeast (Michon et al., 2003; Michon \& Van Balen, 2005; Van Balen et al., 2005). The main depocentre is situated in the northern part of the RVG and shows a subsidence rate of ca. $180 \mathrm{~mm} / \mathrm{ka}$ during the Quaternary. This rate decreases towards $70-80 \mathrm{~mm} / \mathrm{ka}$ in the southern RVG (Houtgast \& Van Balen, 2000; Michon \& Van Balen, 2005). For the German part of the RVG figures of $65-70 \mathrm{~mm} / \mathrm{ka}$ are reported (Boenigk et al., 1979). It should be noticed that the applied age models show slight differences.

As a reference some figures on the thickness of the Quaternary lithostratigraphical units in the RVG are given in Table 1 . The added ages are based on generally used values but should be treated with some care. The data are in accordance with the figures mentioned above.

When the age of the base of the Stramproy Formation is tied to $1.8 \mathrm{Ma}$, as previously assumed, (see above), then the subsidence rates during the deposition of the Stramproy Formation in the southern RVG would be much faster than the Quaternary average value. For example, the part of the Herten borehole (Fig. 2) that is interpreted as representing the Menapian Stage (Zagwijn, 1960) implies a subsidence rate for the period of about $375 \mathrm{~mm} / \mathrm{ka}$, i.e. five times the average rate for the Quaternary (Houtgast \& van Balen, 2000; Michon $\&$ Van Balen 2005). In our opinion such tectonic reconstructions cannot be regarded as realistic and rather they should be attributed to deposition of the Stramproy Formation over a longer period beginning within the Tiglian Stage. This corresponds to the $70-80 \mathrm{~mm} / \mathrm{ka}$ average subsidence rates in the southern RVG reported by other studies. The deviation of this value for reference point RVG-3 (cf. Houtgast \& Van Balen, 2000 ) is related to the diachronous base of the Stramproy Formation, discussed above. 
Table 1. Thickness of Quaternary deposits in the northern and southern RVG.

\begin{tabular}{|c|c|c|c|}
\hline Lithostratigraphical units & $\begin{array}{l}\text { Thickness (m) northern RVG } \\
\text { main depocentre }\end{array}$ & $\begin{array}{l}\text { Thickness (m) southern RVG } \\
\text { Secondary depocentre }{ }^{2}\end{array}$ & $\begin{array}{l}\text { Approximate age } \\
\text { of basal boundary }\end{array}$ \\
\hline All Quaternary Formations & 237.5 & 170 & $2.6 \mathrm{Ma}$ \\
\hline Waalre + Stramproy Formations & 141.5 & 118 & $1.0-2.6 \mathrm{Ma}$ \\
\hline Stramproy Formation overlying Waalre Formation & 26 & 93.5 & $1.0-1.8(?) \mathrm{Ma}$ \\
\hline \multicolumn{4}{|l|}{ Waalre Formation; subunits WA-2 + WA-3 + } \\
\hline Stramproy Formation intercalation & 115.5 & No WA-3 & $1.8(?)-2.2 \mathrm{Ma}$ \\
\hline \multicolumn{4}{|l|}{ Waalre Formation: subunit WA-2 + Stramproy } \\
\hline Formation intercalation & 65.5 & 24.5 & $2.2(?)-2.6 \mathrm{Ma}$ \\
\hline
\end{tabular}

1 Data derived from borehole 51E0159 (Fig 1).

2 Data derived from borehole 58D0885 (Fig 1).

\section{Fluvial history}

The results discussed are in accordance with the concepts of the fluvial history of the LRE (Boenigk, 2002; Kemna, 2005, 2007) and make it possible to extent the reconstructions into the Netherlands (Fig. 9). Four maps, each depicting a specific time slice (indicated in Fig. 7) show an overview of the Late Pliocene to Early Pleistocene fluvial history. The maps show the approximate position for the main pathways of the river systems in the study area. The reconstructions for the eastern part of the LRE are inferred and hamper from severe erosion during the Middle and Late Pleistocene (Boenigk, 2002). The pathways of the Rhine on map A (Fig. 9) correspond to the WA-1 unit of the Waalre Formation and the Oebel beds. Meuse and Rhine had their confluence in the southern RVG near Jülich. The Belgian rivers drained to the NE and had limited sediment supply to the RVG. The next step (Fig. 9B) shows the abandonment of the Rhine from the southern RVG (lower part of the WA-2 unit). At the same time the Rhine continued to flow on the Venlo Block. Sedimentation in the southern RVG is taken over by the Meuse and the Belgian rivers. Further extension of the fluvial domains of the Meuse and Belgian rivers corresponds with the stratigraphical sequences (Fig. 7). The Rhine shifts to a more eastward position on the Venlo Block (Fig. 9C). The final step (Fig. 9D) shows the almost complete blocking of the Rhine drainage system on the Venlo Block. Meuse and Belgian rivers form thick accumulations in the southern RVG and extent well on the Venlo and Peel Blocks.

\section{Conclusions}

- The fluvial history of the SE Netherlands and the adjacent area in Germany is the result of the interaction of three river systems that functioned coevally: Rhine, Meuse and rivers draining the central and northern part of Belgium. The Lower Rhine Embayment in Germany and its continuation into the Netherlands preserves a fragmentary fluvial record spanning the Pliocene and Pleistocene. The fluvial deposits are preserved in longitudinally and laterally variable lithostratigraphical sequences. The depositional architecture, besides revealing a tectonic control on preservation of the deposits, shows diachronic shifts in the distribution of the deposits of the three rivers, with Rhine temporarily leaving southerly depocentres.

- All Pliocene deposits of the three rivers have the same lithological and petrographical signature and cannot easily be differentiated by mapping. They are all assigned to the Kieseloolite Formation. Due to marked changes in petrographical composition, the Late Pliocene deposits of the Rhine can be recognised separately. These deposits can be traced some distance into the RVG and onto its northern shoulder. They form the lowermost part of the Waalre Formation.

- The Lower Pleistocene sedimentary interval is bounded by two major unconformities. The basal one developed after deposition of the Late Pliocene mixed Rhine-Meuse deposits with unstable heavy-0mineral associations. The upper one is the base of coarse gravels of the Sterksel Formation (Netherlands) and Upper Terrace Sequence (Germany) and is of Early Middle Pleistocene age.

The Early Pleistocene interplay of the three dominant river systems resulted in west to east changing lithostratigraphical sequences (Fig. 7). The interfingering of the Stramproy Formation (Belgian rivers) with the Waalre Formation (Rhine) and Holzweiler Formation (Meuse) indicates that at least part of these formations was deposited simultaneously. The long recognised Holzweiler Formation (Meuse), in the central part of the Lower Rhine Embayment, forms the elongation of the East Meuse valley in Southern Limburg. This demonstrates that the East Meuse valley was functioning throughout much of the Early Pleistocene. During deposition of the Holzweiler Formation, sedimentation by the Rhine was forced to leave the RVG. As a consequence, the accommodation space in the southern RVG in the Netherlands was filled by deposits derived from smaller rivers that drained the central and northern part of Belgium. These deposits form the greater part of the 


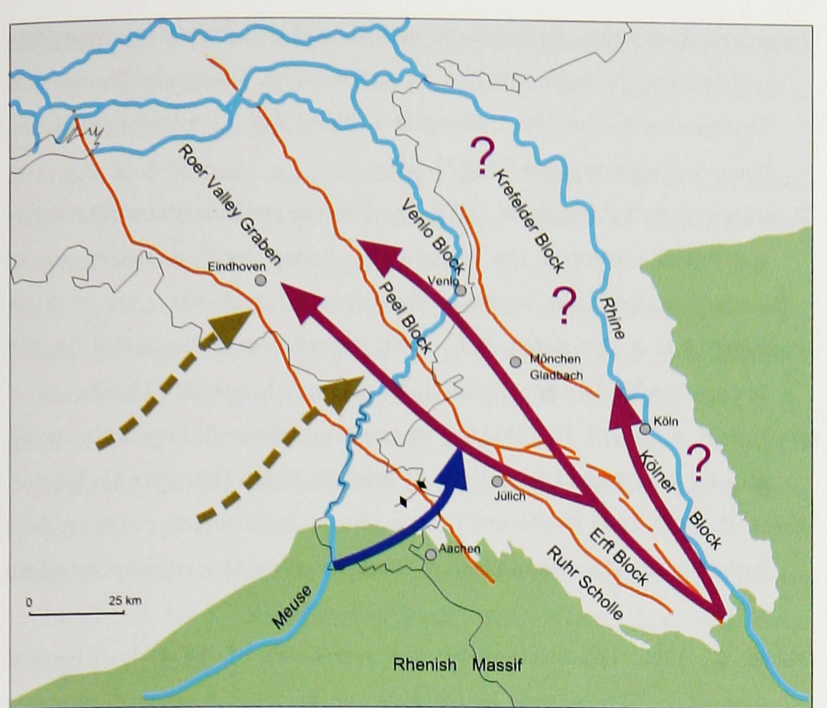

A

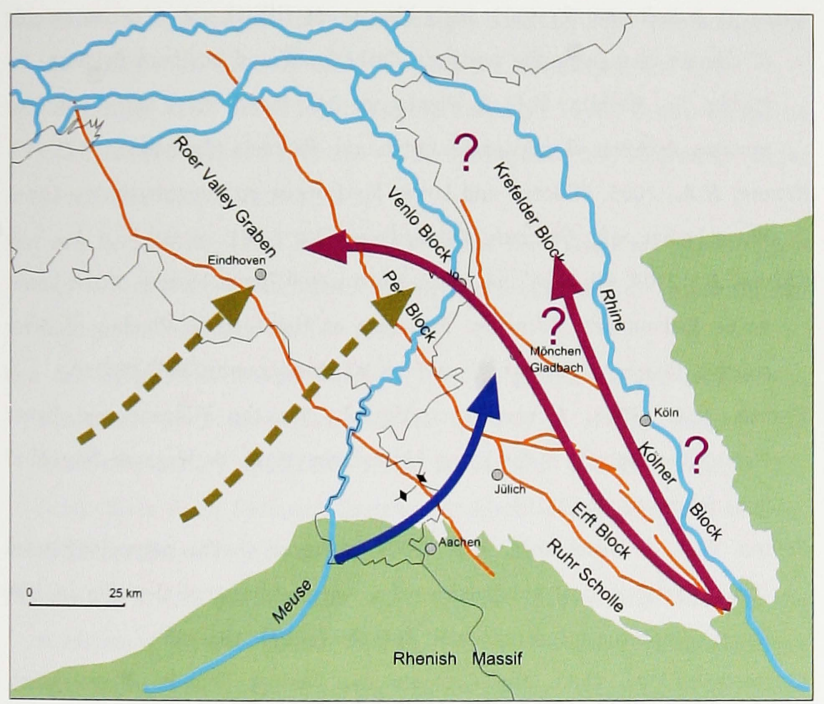

C Rhine

Meuse

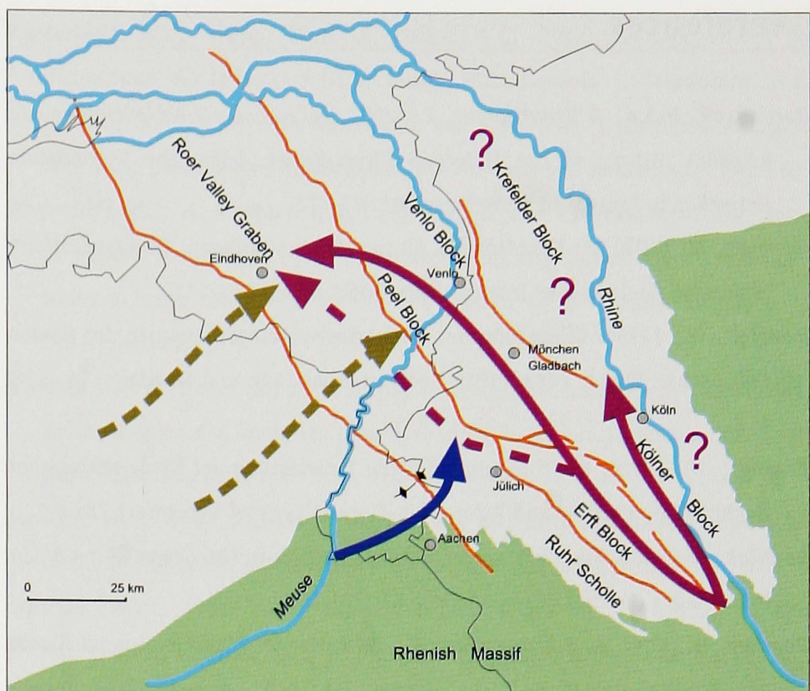

B

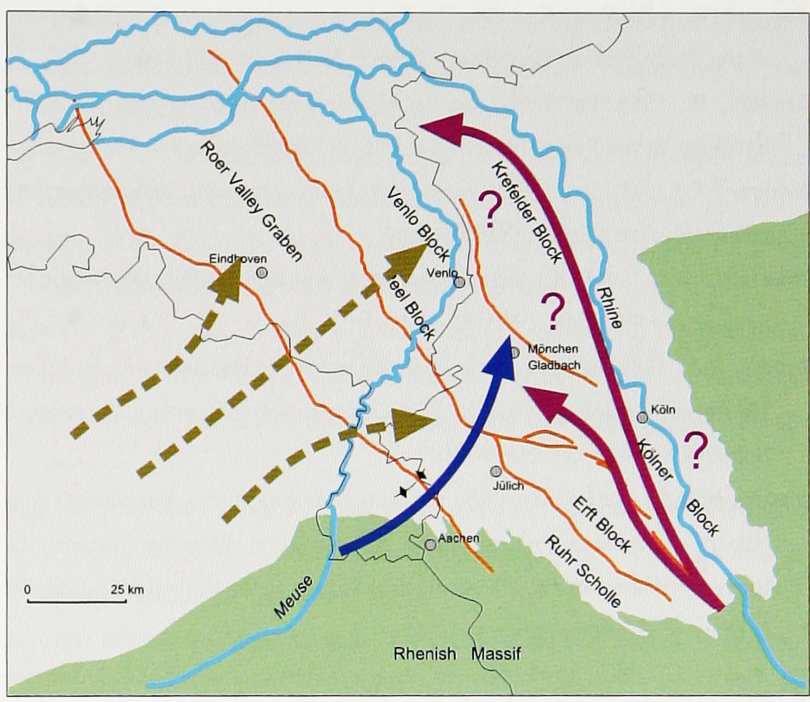

D

\section{Belgian rivers}

Fig. 9. Schematic maps of the Late Pliocene and Early Pleistocene fluvial history in the Lower Rhine Embayment and SE Netherlands (discussion in text). Maps $A, B, C$, and $D$ refer to the time slices indicated in Figure 7.

Stramproy Formation. The base of the Stramproy Formation is considered to be diachronic. The oldest parts of the Stramproy Formation predates the end of the Tiglian Stage.

- The lithostratigraphical framework presented herein serves as a reliable basis for the reconstruction of the fluvial history in the area. Previous reconstructions relied too much on palynological correlations, and took too little consideration of the regional tectonic patterns.

\section{Acknowledgements}

The current study is the result of long discussion and co-operation between the authors, and it is based on numerous field visits and exhaustive examination of the previous literature.
We thank the Geologischer Dienst Nordrhein-Westfalen for co-operation and kindly providing borehole data. Armin Menkovic is thanked for fruitful discussions, and support for reconstruction of tectonic maps and cross-sections. We are greatly indebted to Henk Weerts for critical discussions and encouragement to continue. We are indebted to Kim Cohen, Kees Kasse, Jef Vandenberghe, and Phil Gibbard for their (very) critical and constructive reviews on an earlier version of the manuscript. 


\section{References}

Berendsen, H.J.A. \& Stouthamer, E., 2002. Palaeogeographic evolution and avulsion history of the Holocene Rhine-Meuse delta, the Netherlands. Netherlands Journal of Geosciences 81: 97-112.

Boenigk, W., 1970. Zur Kenntnis des Altquartärs bei Brüggen. Sonderveröffentlichungen Geologisches Institut Universität Köln 17: 1-141.

Boenigk, W., 1978a. Gliederung der altquartären Ablagerungen in der Niederrheinischen Bucht. Fortschritte Geologie Rheinland und Westfalen 28: 135212.

Boenigk, W., 1978b. Die flußgeschichtliche Entwicklung der Niederrheinischen Bucht im Jungtertiär and Altquartär. Eiszeitalter und Gegenwart 28: 1-9.

Boenigk, W., 2002. The Pleistocene drainage pattern in the Lower Rhine Basin. Netherlands Journal of Geosciences 81: 201-209.

Boenigk, W., Koãi, A. \& Brunnacker, K., 1979. Magnetostratigraphie im Pliozän der Niederrheinischen Bucht. Neues Jahrbuch Geologie Paläontologie Monatshefte 1979(9): 513-528.

Boenigk, W. \& Frechen, M., 2006. The Pliocene and Quaternary Fluvial Archives of the Rhine System. Quaternary Science Reviews 25: 550-574.

Breddin, H., 1955. Die Gliederung der altdiluvialen Hauptterrasse von Rhein und Maas in der Niederrheinische Bucht. Der Niederrhein 3-4: 76-79.

Bridge, J.S., 2003. Rivers and Floodplains: forms, processes, and sedimentary record. Blackwell Science Ltd.: $491 \mathrm{pp}$.

Brueren, J.W.R., 1945. Het terrassenlandschap van Zuid-Limburg. Mededelingen Geologische Stichting, C-VI-1: 1-93

Bruins, H.J., 1981. Paleomagnetische datering van de Maasterrassen en VroegPleistocene Lössafzettingen in Zuid-Limburg. Internal report Wageningen University Researchcentre (WUR).

Busschers, F.S., 2007. Unravelling the Rhine; Response of a fluvial system to climate change, sea-level oscillation and glaciation. PhD. dissertation Vrije Universiteit Amsterdam. TNO-Geological Survey of the Netherlands, Utrecht. Geology of the Netherlands 1: 1-183.

De Ploey, J., 1961. Morfologie en Kwartair-stratigrafie van de Antwerpse Noorderkempen. Acta geographica Lovaniensi, 1: $130 \mathrm{pp}$.

Doppert, J.W.C., Ruegg, G.H.J., van Staalduinen, C.J., Zagwijn, W.H. \& Zandstra, J.G., 1975. Formaties van het Kwartair en Boven Tertiair in Nederland. In: Zagwijn, W.H., Van Staalduinen, C.J. (eds): Toelichtingen bij de geologische overzichtskaarten van Nederland, Rijks Geologische Dienst Haarlem: 11-56.

Felder, W.M. \& Bosch, P.B., 1989. Geologisch kaart van Zuid-Limburg en omgeving, 1 : 50 000. Afzettingen van de Maas. Rijks Geologische Dienst, Haarlem.

Fliegel, G. \& Stoller, J., 1910. Jungtertiäre und altdiluviale pflanzenführende Ablagerungen im Niederrheingebiet. Jahrbuch Preußische Geologische Landes-Anstalt 31(I): 227-257

Geluk, M.C., Duin, E.J.T., Dusar, M., Rijkers, R.H.B., Van den Berg, M.W., Van Rooijen, P., 1994. Stratigraphy and tectonics of the Roer Valley Graben. Geologie en Mijnbouw 73: 129-141.

Gliese, J. \& Hager, H., 1978. On browncoal resources in the Lower Rhine Embayment (West Germany). Geologie en Mijnbouw 57: 517-525.
Hagedorn, E.-M., 2004. Sedimentpetrographie und Lithofazies der jungtertiären und quartären Sedimente im Oberrheingebiet. Inaugural-Dissertation Geologisches Institut der Universität zu Köln: 248 pp. http://kups.ub.unikoeln.de/volltexte/2004/1253/

Hagedorn, E-M. \& Boenigk, W., 2008. The Pliocene and Quaternary sedimentary and fluvial history in the Upper Rhine Graben based on heavy mineral analyses. Netherlands Journal of Geosciences 87/1: 21-32.

Houtgast, R.F. \& Van Balen, R.T., 2000. Neotectonics of the Roer Valley Rift System, the Netherlands. Global and Planetary Change 27: 131-146.

Juvigné, E. \& Renard, F., 1992. Les terrasses de la Meuse de Liège a Maastricht. Annales de la Société Géologique de Belgique T. 115 (fasicicule 1): 167-186.

Kasse, C., 1988. Early Pleistocene tidal and fluvial environments in the southern Netherlands and northern Belgium, Dissertatie Vrije Universiteit Amsterdam: $190 \mathrm{pp}$.

Kasse, C., 1990. Lithostratigraphy and provenance of the Early-Pleistocene deposits in the southern Netherlands and northern Belgium. Geologie en Mijnbouw, 69-4: 327-340.

Kasse, C. \& Bohncke, S., 2001. Early Pleistocene fluvial and estuarine record of climate change in the southern Netherlands and northern Belgium. In: Maddy, D., Macklin, M.G. \& Woodward, J.C. (eds): River basin sediment systems. Archives of environmental change. Balkema (Rotterdam): 171-193

Kemna, H.A., 2005. Pliocene and Lower Pleistocene stratigraphy in the Lower Rhine Embayment, Germany. Kölner Forum 14: 1-121.

Kemna, H., 2007. Pliocene and Lower Pleistocene fluvial history of the Lower Rhine Embayment, Germany: Examples of the tectonic forcing of River courses. Quaternary International. doi.10.1016/j.quaint.2007.08.038.

Kemna, H.A., 2008. A revised stratigraphy for the Pliocene and Lowe Pleistocene deposits of the Lower Rhine Embayment. Netherlands Journal of Geosciences 87/1: 91-105.

Kemna, H.A. \& Westerhoff, W.E., 2007. Remarks on the palynology-based chronostratigraphical subdivision of Pliocene terrestrial deposits in NWEurope. Quaternary International, 164-165 (2007): 185-196

Klostermann, J., 1983. Die Geologie der Venloer Scholle (Niederrhein) Geologisches Jahrbuch A 66: 3-115

Kurtz, E., 1913. Die Verbreitung der diluvialen Hauptterrassenschotter von Rhein and Maas in der Niederrheinischen Bucht. Verhandlungen der Naturhistorische Vereins, Jahrgang 70: 87-108.

Kuyl, O.S., 1980. Toelichtingen bij de geologisch kaart van Nederland, $1: 50000$ Blad Heerlen, 62W-620. Rijks Geologische Dienst, Haarlem. 1-206.

Macar, P., 1976. Les mouvements épéirogeéniques decelables en Belque. L'aide de la Géomorphologie. In: Pissart, A. (ed.): Géomorphologie de la Belgique Université de Liége, 1976: 29-49.

Miall, A.D., 1996. The Geology of Fluvial Deposits. Sedimentary Facies, Basin Analysis, and Petroleum Geology. Springer (Berlin): $582 \mathrm{pp}$

Michon, L., Van Balen, R.T., Merle, O. \& Pagnier, H., 2003. The Cenozoic evolution of the Roer Valley Rift System integrated at a European scale. Tectonophysics, 367: 101-126.

Michon, L. \& Van Balen, R.T., 2005. Characterization and quantification of active faulting in the Roer valley rift system based on high precision digital elevation models. Quaternary Science Reviews 24: 455-472

Pissart, A., 1974. la Meuse en France et Belgique. In: Macar, P. (ed): L'évolution Quaternaire des bassins fluviaux de la Mer du Nord meridionale. Soc. geol. de Belgique, Liege: 105-131. 
Schnütgen, A., 1974. Die Hauptterrassenfolge am linken Niederrhein aufgrund der Schotterpetrographie. Forschungsberichte des Landes NordrheinWestfalen, Nr. 2399: 1-149.

Tavernier, R. \& De Moor, G., 1974. L'évolution du basin de l'Escaut. In: Macar, P. (ed.): L'évolution Quaternaire des basins fluviaux de la Mer du Nord méridionale. Soc. Géol. de Belgique (Liège): 159-231.

Tesch, P., 1908. Der Niederländische Boden und die Ablagerungen des Rheines und der Maas aus der jüngeren Tertiär- und der älteren Deluvialzeit. Mededelingen van de Rijksdienst der 0psporing van Delfstoffen No. 1: 1-74.

Tesch, P., 1941. De schiervlakte van Eifel en Ardennen voor de opheffing tot Bergland. Tijdschrift Nederlandsch Aardrijkskundig Genootschap, 2e serie, deel LVIII: 63-71.

Urban, B., 1978a. Vegetationsgeschichtliche Untersuchungen zur Gliedrung des Altquartärs der Niederrheinischen Bucht. Sonderveröff. Geol. Inst. Univ. Köln. 34: 1-65.

Urban, B., 1978b. The interglacial of Frechen I/Rheinland - a section of the Tiglian A type. Geologie en Mijnbouw 57: 401-406.

Van Balen, R.T., Houtgast, R.F. \& Cloetingh, S.A.P.L., 2005. Neotectonics of the Netherlands: a review. Quaternary Science Reviews 24: 439-454.

Van den Berg, M.W., 1989. Toelichting op kaartblad 59-62, Geomorfologische kaart van Nederland, 1: 50000 - DL0 Staringscentrum, Wageningen/Rijks Geologische Dienst Haarlem: 1-32.

Van den Berg, M.W., 1994. Neotectonics of the Roer Valley rift system. Style and rate of crustal deformation inferred from syn-tectonic sedimentation. Geologie en Mijnbouw 73: 143-156.

Van den Berg, M.W. \& Van Hoof, T., 2001. The Maas terrace sequence at Maastricht, SE Netherlands: evidence for $200 \mathrm{~m}$ of late Neogene and Quaternary surface uplift. In: Maddy, D., Macklin, M.G. \& Woodward, J.C. (eds): River Basin Sediment Systems: Archives of Environmental Change, Balkema (Rotterdam): 45-86,

Van der Vlerk, I.M. \& Florschütz, F., 1953. The palaeontological base of the subdivision of the Pleistocene in the Netherlands. Verhandelingen Koninklijke Nederlandse Akademie Wetenschappen Afdeeling Natuurkunde 1e Reeks 20: 1-58.

Van Straaten, L.M.J.U., 1956. Structural features of the 'Papzand' Formation at Tegelen (Netherlands). Geologie en Mijnbouw 18: 121-135

Vandenberghe, J. \& De Smedt, P., 1979. Palaeomorphology in the eastern Scheldt basin (Central Belgium)-The Dijle-Demer-Grote Nete confluence area. Catena 6: 73-105

Vandenberghe, N., Laga, P., Louwye, S., Vanhoorne, R., Marquet, R., De Meuter, F., Wouters, K., \& Hageman, H.W., 2005. Stratigraphic interpretation of the Neogene marine - continental record in the Maaseik well (49W0220) in the Roer Valley Graben, NE Belgium. Memoirs of the Geological Survey of Belgium 52: 1-39.

Weerts, H.J.T., 1996. Complex Confining Layers. Nederlandse Geografische Studien, 213: 1-189.

Weerts, H., Cleveringa, P., Ebbing, J.H.J., De Lang, F.D. \& Westerhoff, W.E., 2003. De lithostratigrafische indeling van Nederland. Formaties uit het Tertiair en Kwartair. Rapport NITG-TNO 03-051-A (Internal report TNO Geological Survey of the Netherlands).

Westerhoff, W.E., 2004. Upper Pliocene and Lower Pleistocene Rhine-Meuse deposits in the Tegelen-Reuver type area. With contributions by H.A. Kemna. DEUQUA meeting 2004 Nijmegen Excursion guide: 79-130
Westerhoff, W.E., Wong, Th.E. \&. Geluk, M.C., 2003. De opbouw van de ondergrond. In: De Mulder E.F.J., Geluk, M.C., Ritsema, I., Westerhoff ,W.E. \& Wong, Th.E. (eds): De ondergrond van Nederland. Nederlands Instituut voor Toegepaste Geowetenschappen TN0. Geologie van Nederland 7: 247-352.

Westerhoff, W.E., A. Menkovic \& De Lang, F.D., in prep. A revised lithostratigraphy of Upper Pliocene and Lower Pleistocene deposits derived from the RhineMeuse-Schelde catchments in the Netherlands (NJG - Lithostratigraphy of the Netherlands).

Wunstorf, W. \& Fliegel, G., 1910. Die Geologie des Niederrheinischen Tieflandes. Abhandlungen der Königlich Preußischen Geologischen Landesanstalt. Neue Folge, Heft 67: 1-172.

Zagwijn, W.H., 1960. Aspects of the Pliocene and Early Pleistocene vegetation in the Netherlands. Mededelingen Geologische Stichting C-III-1(5): 1-78.

Zagwijn, W.H., 1963. Pollen-analytic investigations in the Tiglian of the Netherlands. Mededelingen Geologische Stichting. Nieuwe Serie 16: 49-71.

Zagwijn, W.H., 1974. Pollenanalytisch onderzoek van een humeuze kleilaag in de groeve bij Süsterseel en een opmerking n.a.v. rapport 369. Intern rapport Paleobotanie 719. Rijks Geologische Dienst (presently at the files of TNO).

Zagwijn, W.H., 1985. An outline of the Quaternary stratigraphy of the Netherlands. Geologie en Mijnbouw 64: 17-24.

Zagwijn, W.H., 1989. The Netherlands during the Tertiary and Quaternary: a case history of Coastal Lowlands evolution. Geologie en Mijnbouw 68: 107-121.

Zagwijn, W.H., 1992. The beginning of the ice age in Europe and its major subdivisions. Quaternary Science Reviews, 11: 583-591.

Zagwijn, W.H., 1998. Borders and boundaries: a century of stratigraphical research in the Tegelen-Reuver area of Limburg (the Netherlands). Mededelingen Nederlands Instituut Toegepaste Geowetenschappen TN0 60: 19-34.

Zagwijn, W.H. \& De Jong, J., 1963. Pollenanalytisch materiaal uit een groeve te Platte Bosschen. Intern Rapport Paleobotanie 369. Rijks Geologische Dienst (presently at the files of TNO).

Zagwijn, W.H. \& De Jong, J., 1984. Die Interglaziale von Bavel und Leerdam und Ihre Stratigraphische Stellung im Niederländischen Früh-Pleistozän. Mededelingen Rijks Geologische Dienst 37-3: 155-169.

Ziegler, P.A., 1994. Cenozoic rift system of western and central Europe: an overview. Geologie en Mijnbouw 73: 99-127.

Zonneveld, J.I.S., 1949. Zand-Petrologische onderzoekingen in de terrassen van Zuid-Limburg. Mededelingen Geologische Stichting, Nieuwe Serie No. 3: 103-123

Zonneveld, J.I.S., 1955. De Kwartaire rivierterrassen van Zuid-Limburg. Tijdschrift Koninklijk Nederlands Aardrijkskundig Genootschap: 72.

Zonneveld, J.I.S., 1957. River terraces and the Quaternary chronology in the Netherlands. Geologie en Mijnbouw N.S. 19: 277-285. 